\title{
Pressing Pause: Critical Reflections from the History of Media Studies
}

\author{
Brian Dolber* and Andrew O’Baoill** \\ *California State University, San Marcos, San Marcos, United States, \\ bdolber@csusm.edu
}

**National University of Ireland Galway, Galway, Ireland, Andrew.obaoill@nuigalway.ie

\begin{abstract}
This article examines the history of the fraught relationship between the fields of media and journalism studies and the media industries in the US and UK contexts. In the US, journalism programmes were built on instituting professionalism, and media studies arose in conjunction with the demands of a growing industry. In the UK, cultural studies developed in conjunction with the need to produce a working class that could make sense of the mass media environment. Under neoliberalism, however, professionalism in both media and the academy have been undercut, while media studies programmes have expanded. We argue that a historical, political economic orientation demonstrates that media studies faculty and students are subject to many of the same institutional pressures, providing fertile ground for new pedagogical approaches.
\end{abstract}

Keywords: Political Economy, Media Studies, Neoliberalism, Media Industries, Pedagogy, Labour

Acknowledgement: Support for this work was provided by the Moore Institute for the Humanities and Social Sciences at the National University of Ireland Galway.

While it has become commonplace to bemoan the growing global emphasis on STEM fields at the expense of history, literature, philosophy, and languages, Lionel Pilkington (2013), a historian of Irish theatre, has pointed to another concern - the instrumentalisation of the humanities themselves, in conjunction with the market's increasingly draconian demands. Arguing that "the work of humanities disciplines can be reconciled, without too much difficulty, with profit-based economic value", he is particularly troubled by a tendency to present the humanities as "worthy of support because they contribute to economic utility and, specifically, to entrepreneurialism, urban renewal and the accumulation of shareholder profits". Such arguments, he believes, render the humanities ineffectual as facilitators of reflection and social critique.

Similarly, Irish President Michael D Higgins, himself a former academic, cautions against reducing higher education "to that of provider of any narrow professional training, guided towards a specific and limited objective, and essentially disengaged from the academic experience which is fundamental to independent thought and scholarly engagement" $(2016,35)$. Like Pilkington, Higgins is concerned with an increasingly narrow conceptualisation of the university as a site for producing skilled labour - or, variously, as a service provider for student clients hoping to 'upskill' and prepare themselves for the job market. 
If this might be said of the humanities broadly, it is of particular interest to those in media, journalism, and communication studies (MJCS). This area has come to constitute what Toby Miller terms "Humanities II" - a field designated for the middleand working-class students at state institutions in the US, in contrast with more traditional fields such as literature, history, and philosophy offered at the "finishing schools" of the Ivy League $(2014,1)$. While student enrolments in the humanities, social sciences, mathematics, physical sciences, and psychology dropped from 47 percent to just 26 percent between 1968 and 1986 (Ferrara 2015, 119), MJCS degrees became more prevalent. In 1970, they accounted for 1.3 percent of all U.S. undergraduate degrees; by 1989 they accounted for 5 percent and have held at that since. However, traditional humanities and social science programmes continue to shrink, both in terms of allocated funding and number of degrees offered, with the balance awarded in a host of other professionally-oriented programmes such as business, the health professions, and other "practical fields" (Bui 2017).

Although Miller (2014) argues that traditional humanities fields remain more intact outside of the US, Terry Eagleton (2010) believes they receive some level of protection by the American system's reliance on general education requirements. In Britain, he claims the state of affairs is more dire, as "the role of academia has been to service the status quo, not challenge it in the name of justice, tradition, imagination, human welfare, the free play of the mind or alternative visions of the future" since the Thatcher years.

In this context, students and faculty cite the supposed practicality of a MJCS degree as the main reason for the major's prevalence. As Communications Studies professor at University of Montana Betsy Bach was quoted in a Huffington Post column, "I think as students become a little more careerist they search for a degree that is flexible and adaptable and I think communication provides for both of those" (Schmitt 2014).

The field's pre-professional reputation, however, has led many to believe MJCS plays second fiddle intellectually to its more prestigious counterparts. Robert McChesney (2004a) argues that it "has settled into a second-tier role in U.S. academic life, providing mostly inconsequential research." As he notes, the field is bolstered by "undergraduate demand for training and degrees leading to employment in the media/information sector," which protects its claim to "a distinct and necessary research enterprise" from being questioned. Indeed, Mattelart and Mattelart (1998, 156) point to a "worldwide generalisation" of symbiosis between media industries and researchers, with "increasing professionalism of careers" reliant on legitimation from education and "operational research", and consequent challenges for the legitimacy of the field.

This relationship between MJCS, the media industries, and students demands further attention. As McChesney has noted elsewhere, critiques of the media often take the form of blaming audience tastes, internalising the industry's dictum that "the media give people what they want" (2004b, 198-205). Similarly, if MJCS teaches students how to use Twitter, create advertisements, and develop technical skills, it's presumably because that's what students demand. In an environment where institutions must compete for resources, and where programmes within those institutions compete among each other, professors ignore the consumer at their peril.

The demand for MJCS degrees fosters an illusion that programmes might be insulated from the larger cuts at academic institutions, or that they might be able to argue for increased resources predicated on customer demand. The bubble, however, may soon burst. Falling wages have prompted discussion about whether or 
not a college degree is necessary at all, a conversation that would have been virtually unthinkable a decade ago in the United States. While the numbers still indicate that a degree translates into higher salaries, this is in comparison to the falling wages of workers without higher education (Reich 2014). According to a Pew survey (2017), only 55 percent of Americans believe that universities have a positive impact on society, while 58 percent of Republicans believe that they are detrimental. Simultaneously, employment in the media industries has been dramatically altered, making MJCS degrees a less likely pathway to illusory stable, professional employment.

While a variety of stakeholders offer technocratic approaches, ensuring that students are prepared for an unpredictable job market and that programmes retain credibility and viability, we believe the twin crises in media and higher education provide an opportunity to assess the importance of MJCS education beyond its exchange value. Our field provides us with the tools to make sense of this conjuncture. Drawing on MJCS' political economy tradition, we conceptualise 'the media' as a broadly defined set of institutions and practices that are connected to larger structural forces. Rather than being purely descriptive, political economy allows us to take a critical and moral perspective as we explore MJCS' history and relationship to media industries in both the US and the UK.

In this essay, we draw on a range of extant literature to develop a framework for critical pedagogies of MJCS. While the field often serves the economic needs of the industry it analyses, it also contains seeds of resistance, the critical Marxist and cultural traditions in our field. In our moment of crisis, these seeds must be resown and cultivated to grow branches of solidarity between students and faculty that might transform our media and academic institutions.

\section{A Brief History of Media and Media Studies}

A political economic perspective on MJCS must grapple with the historical relationships between academic institutions and industry demands. While such relationships are not new - it would be impossible to study media without 'the media' existing as both institutions and cultural forms - the ways in which academic and media institutions have interfaced with each other, and the value the academy has contributed to commercial media systems demands interrogation as a defining feature of their shared political economy. The point here is not that MJCS is particularly corrupted because of its links to industry, or that its intellectual rigour has been sullied by such mundane concerns. Indeed, the history of any discipline would reveal severe limitations of the types of questions asked and research undertaken based on institutional and cultural biases. Rather, we endeavour to understand the particular economic work that MJCS performs in relation to an industry that has become centrally important under neoliberal capitalism.

In the US, the relationship between MJCS and 'the media' extends back to the field's pre-history, with the founding of journalism schools in the early twentieth century. Amidst fears of public manipulation and crass commercialism, journalism schools began to train a new cadre of professionalised (if not wholly professional) reporters. With degrees in hand, graduates would offer credibility to growing monopolistic newspaper chains.

In 1904, Joseph Pulitzer argued that journalism schools would provide the growing industry with an apprenticeship system housed inside universities, justifying his recent million-dollar endowment of Columbia University's School of Journalism. While other elite institutions were more reticent towards developing professional education, 
land-grant institutions in the South and Midwest - including the Universities of Missouri, Illinois, and Wisconsin - founded journalism schools in accordance with the demands of the newspaper industry. "Journalism education spread not because journalists needed college degrees", according to John Nerone (2015, 162), "but because it served the social and political interests of the press".

By relying on a professionalised workforce, the press could counter criticisms of bias and corruption based on commercial interests. As credentialing bodies, 'jschools' fulfilled their role in an ideological project, bolstering a profitable industry by acting as gatekeepers for entrance to particular labour pools. Thus, they became central to preserving the autonomy of a for-profit news industry dependent on advertising revenue. As democracy's viability became suspect over the next decades - from the Lippmann-Dewey debates of the 1920s, to the global political upheaval inspired by the Great Depression, to the fears of authoritarianism stoked by World War II and the early Cold War - professionalism became solidified as a journalistic norm.

In 1947, the Hutchins Commission Report on Freedom of the Press solidified a "postwar settlement" for US media, and allowed for a privately-owned press with minimal government interference, given that professional standards forced these large, advertising-dependent companies to report with a sense of social responsibility (Pickard 2014). That same year, Wilbur Schramm and an array of other researchers from across the social sciences initiated the field's first PhD-granting programme at the University of Illinois' Institute for Communications Research. There, Schramm, Frederick S. Siebert and Theodore Peterson further solidified support for "social responsibility", distinguishing US journalism from authoritarian, Marxist, or wholly libertarian models, as eventually delineated in the classic Four Theories of the Press (1956). As Nerone et al. argue, the volume was shaped by "the alliance between journalism educators and the communications business" - as Siebert had been legal counsel to the Illinois Press Association and the Chicago Tribune and Peterson's mentor - as well as the period's "cold war mentality" - as Schramm had conducted research on behalf of the military and had consulted for a variety of federal agencies (1995, 8; 8-13).

But by this point, discussion of 'the media' was displacing that of 'the press'. Nerone (2015) dates the term's emergence to the 1920s, as it came to refer to things that carried advertising by advertising agencies, both in print and on radio programmes. By the 1930s, social scientists adopted it, and newspapers, magazines, radio and motion pictures were all collectively dubbed "the mass media" in common parlance $(2015,144)$. During these years, crusaders such as the Payne Fund placed moralism ahead of social science, funding studies on the effects of motion pictures (Jowett et al. 1996). Similarly, the advocacy group Consumers' Research (CR) presumed that consumers could be easily manipulated by advertising, and scientifically tested products to determine how people might best spend their money (Stole 2005). As the film industry consolidated and the advertising industry successfully thwarted reform efforts in the 1930s, media companies themselves relied on social science researchers. Paul Lazarfeld's 'administrative research' at Columbia and Princeton placed social science in the service of CBS through a series of audience studies funded by the Rockefeller Foundation, beginning in 1938. Now, "mutual interest in audiences as sets of empirical data that could explain trends sociological, political, consumerist - led media corporations and academics to pool their intellectual and financial resources in pursuit of the reading, listening, and viewing habits of the American public" (Jenemann 2007, 9). 
Schramm and others continued this trajectory, investigating the psychological, political, and social effects of mass communication. Indeed, Schramm was less interested in journalism and more interested in its antithesis - propaganda reflecting the growing concern for the potential for influence and persuasion towards anti-democratic ends among liberals during the first half of the twentieth century (Nerone et al. 1995, 8-13). Christopher Simpson has noted the attractiveness of positivistic approaches to mass communication to state actors intent on developing "tools for social management" and "communication-as-domination" (Simpson 1994, 3) Thus, MJCS research has long been tied to industry and state imperatives, helping to ensure that the commercial media system serves the demands of liberal democracy while also protecting the profit margins of newspaper publishers, broadcasting corporations, and motion picture studios. Or, to put it more accurately, the media industries and government have long relied upon academic labour in order to further their economic and strategic goals.

This is not to say scholars have always sought to serve industry or state interests, as spaces for critical analysis did emerge. Traditions rooted in Marxian and social democratic perspectives developed as scholars sought to resist the dominant paradigm and critique the culture industries. Jenemann (2007) notes that Theodor Adorno's work on the Princeton Radio Research Project - intimately linked to forms of audience monitoring, as well as efforts to enhance the production of commodity audiences and to extract as much value as possible from their unpaid labour, for example - inspired his critical essays. Further, the founding of political economy as a sub-field grew from Dallas Smythe's work as an economist within New Deal-era federal agencies, including the FCC (Mosco 2009, 83). Similarly, Charles Siepmann, a former programming director at the BBC who contributed to the FCC's effort to define its public interest standards in the controversial 1946 Blue Book, became the first director of NYU's Communications in Education Department (Pickard 2014, 66; 121). Thus, critical scholarship developed as externalities of state-corporate research, as scholars reflected upon experiences within the communications apparatus.

Although its role has fluctuated at various historical moments, critical research has always occupied a marginal space within the field, even as it has helped provide MJCS with intellectual credibility and a claim to the liberal arts tradition. As US journalism reached its "high modernist" apex, and a consolidated culture industry achieved global hegemony (Hallin 1992, 14-25; Schiller 1992), television and film became legitimate objects of study and industries to enter with baccalaureate degrees. At the same time, the GI Bill and the civil rights and feminist movements helped to make college education more accessible, if not more essential, for success in the job market among growing populations (Aronowitz 2000).

Academic inquiry within the UK also responded to the postwar rise of a culture industry that demanded the working class attain new forms of literacy. Work in adult education inspired founders of the British cultural studies tradition, including Raymond Williams, E.P. Thompson, and Richard Hoggart, to develop a "national perspective and common concerns for education, popular cultural forms, and the 'lived' experience of class" representing "a continuity in English cultural criticism that survived in the immediate directions cultural studies would take" (Lee 2003, 37). Williams, for example, worked from 1946 through 1961 with the Workers' Educational Association (WEA) in Oxford, an early British adult-education system that provided classes in "Public Expression" (O'Connor 1989, 9). He would later extend "new 
methods of teaching [literature] to material outside the literary canon: film, advertisements, and the mass media".

While Williams and Hoggart saw the WEA as a "working-class educational movement", as opposed to those who "wanted courses related to the vocational needs of students", by 1960, the vocational vision won out (Ibid., 10). Williams moved to work at Cambridge, where he completed Communications. There, he proposed a critical approach to the teaching of cultural work that was, nonetheless, grounded in "personal practice, direct experience of the arts, understanding of the institutions" (1975/1962, 146). Acknowledging that "a good deal of scattered material and experiment is ready to draw on", Williams advocated for the establishment of both a "Communications Centre" that might supply teaching materials related to the field, and "an Institute of Communications Research, at university level, undertaking longrange research and analysis" (Ibid., 149). Around this time, Hoggart "was approached to occupy a second chair in English at the University of Birmingham", leading in 1964 to the founding of such an institute - the Centre for Contemporary Cultural Studies (CCCS) with Stuart Hall on staff (Lee 2003, 75). By 1975, Williams could claim that "there has been a significant development of communications studies in education, in the schools, in further and adult education, in the polytechnics, and even in a few universities" $(1975 / 1962,182)$.

Mirroring developments in North America, a political economy tradition also emerged in the UK. Steering away from Birmingham's culturalism, it argued that "mass media are first and foremost industrial and commercial organizations which produce and distribute commodities" (Murdock 1974, 205-6, quoted in Wasko 2014). Stuart Hall believed this approach tended towards a functionalism that "sacrifices too much of what has been painfully secured [through neo-Marxist criticism] without a compensating gain in explanatory power" $(1980,71)$. However, Smythe (1977) argued that the British approach remained too focused on media content and elided structural understandings. The North American "Schiller-McChesney" school focused on an analysis of media systems (Hesmondhalgh 2002, 33-35), having grown out of industry demands; British political economy continued the conversation about ideology and its relationship to class formation in a social democratic context.

Expansion of university-level education did provide opportunities for working-class students to join the growing cultural and creative sectors. James D. Halloran, founding director of the Centre for Mass Communication Research at the University of Leicester, had also been a WEA staff member, though with a grounding in social scientific analysis rather than literary critique (Allaway 1967). But by 1969, communication research reached a turning point internationally, as UNESCO engaged with IAMCR and began to transition "from a conventional, mainly service, administrative and western dominated approach, to a more critical approach with a wider sociological orientation" (Halloran 1995). Halloran used a similar phrasing to describe the early research agenda of the Centre for Mass Communication Research at Leicester as marking a shift from

"an uncritical, administrative approach with a psychological orientation which served the system, to a more critical, sociological stance which sought to challenge basic assumptions, question the accepted way of doing things, spell out implications in societal terms and, where possible, suggest alternatives" (Halloran 1999). 
In many ways, this committee paralleled the earlier work of the Hutchins Commission, where elite investigation into the problems of journalism helped generate important structural critiques (Pickard 2014). But while the Hutchins Commission ultimately minimised its more radical elements, the Centre consciously sought to push back against the narrow administrative US model. Criticising Elihu Katz's report on UK media research as too timid, Halloran (1978) hoped to develop a media studies that paid closer attention to society and lived experience, and that would be critical of institutions and content.

These possibilities would be limited, though, as both the media industries and the academy became sites of neoliberal experimentation in the 1970s and 1980s. UNESCO took a major hit when the United States withdrew from the body in 1983, following a lengthy global debate over the New World Information and Communication Order, in which newly independent nations attempted to repair the global flows of communication that had been set by imperialist objectives during the preceding century. The UK followed suit two years later. In the meantime, neoliberal logic began to shape domestic media and telecommunications policy on both sides of the Atlantic. In the US, the FCC repealed its Fairness Doctrine and syn-fin rules, and telecommunications markets, following the breakup of AT\&T, became deregulated. Governments around the world offered tax incentives and cheap labour to spur 'Hollywood' film production. In the UK, Thatcher's war on the BBC represented a significant front in an international development that led Rowland and Tracey (1990, 8 ) to argue that "Public broadcasting institutions and the notions of cultural and political discourse that undergird them seemed everywhere to be under serious attack", from right-wing challenges to the notion of "public culture", cuts in public funding, and competition with commercial broadcasters.

Thus, as deregulation - or, to be more accurate, reregulation in favour of corporate capitalism - enabled the expansion of multinational media conglomerates in the 1980s and 1990s, journalism became incorporated into a larger culture industry focused on producing profitable entertainment (Bagdikian 2000). Although a movement for public journalism emerged in the 1990s, and the era of convergence inspired more wide-ranging critiques of corporate media, the fundamentals of media economics remained "off-limits" for much academic inquiry (McChesney 1992). While neoliberals declared that there was 'no alternative', and that we had reached history's end, the future would be one in which there was a continuing heightening of the role of capitalism in shaping our media environment.

In the coming years, these structural dynamics would erode professionalism within both the media and the academy. As journalism has been decimated by commercial pressures, MJCS programmes have come to emphasise attainment of technical skill rather than a disciplined ethos of independence. In the meantime, academic labour has been subjected to its own Taylorisation.

\section{The Neoliberal Academy and Transformations in Media Employment}

As the neoliberal project expanded within both the media and academic sectors, the nature of employment transformed in both realms as well. By May 2016, approximately 1.9 million workers (about $1.35 \%$ of those employed in the United States) were classified as working within the "Arts, Design, Entertainment, Sports, and Media Occupations". Mean annual income for the sector, at just over $\$ 58,390$, is somewhat higher than the national average of $\$ 49,630$ (U.S. BLS 2016). In the European Union, another 1.8 million people are employed in the publishing, audio- 
visual and information service sectors, part of the broader NACE $\mathrm{J}$ category that also includes the larger telecommunications and computers sectors (Eurostat 2016).

The lacklustre pay is in no way due to a lack of education among the media workforce. While since at least the early 1970s a majority of journalists had college degrees, today 92 percent claim this mantle, compared to only 30 percent of the general US population. Although about half of all journalists held MJCS degrees in 2003, male journalists earn approximately $\$ 53,600$ annually, about 35 percent lower than an inflation-adjusted salary in 1970. Female journalists fare worse, earning approximately $\$ 0.82$ to the dollar (Thomson 2014). According to some estimates, it would cost the average advertising or promotions specialist five years to pay off their student debt, and a public relations specialist up to 12 years, while it would cost the average journalist attending an in-state public university 22 years (Kahn 2015).

A 2013 Poynter Institute survey noted that while 96 percent of journalism educators see a journalism degree as central to understanding "the value of journalism", only 57 percent of professionals in the field agree. As Howard Finberg, the Institute's Director of Partnerships and Alliances, notes, "Disruption, driven by economics and technology, is coming to the university system much more quickly than most administrators realize" (2013). While MJCS enrolment remains "embarrassingly high" and hiring within media organisations is "at an all-time low", Finberg asserts, "When it comes to value for dollars invested, journalism degrees may have much less value than they did in the past".

Despite his structural analysis, though, Finberg elides a structural solution. Instead, he argues that the cures for economic disruptions in the industry are disruptions in the classroom. "Journalism education will undergo fundamental shifts in how journalism is taught and who teaches it. Those who don't innovate in the classroom will be left behind - just like those who chose not to innovate in the newsroom."

In accordance with student demand, however, MJCS has grown enormously in the last two decades. In the UK, the number of universities and colleges that offer degrees in media studies tripled between 1996 and 2009. Within the US, the Society for Cinema and Media Studies estimates that there are 229 bachelors'-level programmes. But it is unclear that students are truly benefiting from this system. In fact, the popularity of MJCS is somewhat perplexing given the deprofessionalisation of media work (Dove-Viebahn 2015).

Consider the following promised remuneration recently touted in a request received by one of the authors. In return for several weeks of work on a digital marketing campaign, graduates are offered "highly relevant industry experience for their CV, LinkedIn endorsements, a written reference" (Shepherd 2012). Glowing reports on tasks completed are increasingly offered as sufficient recompense for labour provided - presumably to be traded in for future opportunities to provide labour on less onerous terms. Kuehn and Corrigan (2013) have previously explored this concept in the concept of online social media production, examining both firms that structure their business model around voluntary labour - e.g. online platforms such as Yelp and SBnation - and those that "benefit from the training grounds that the former firms provide [as ...c]osts associated with training, professional development and the location of top talent are offset by the free pool of hope labourers competing for attention on the social web."

The example above points, though, to an intensification of this process, whereby the acceptance of unpaid labour as part of the development process is being leveraged by firms to push the bounds of the situations within which labour is 
provided for free. Internships serve as the university's primary mechanism for fitting students into this 'flexible' workplace structure. As universities themselves face budget crises, academic programmes can offer the promise of professional skills in a competitive environment to students while collecting tuition dollars for education provided primarily off-site. While faculty members typically must provide some supervisory component to ensure that students are gaining some educational value, by offering credit for these experiences, universities are in danger of reducing themselves to credentialling services while outsourcing educational experiences to the private sector.

There have been a small number of cases in which what Ross Perlin (2013) bluntly terms "wage theft" have been highlighted, challenged, and rectified, such as that of 'interns' on the set of Fox Searchlight's Black Swan. The film, which grossed over $\$ 300 \mathrm{~m}$, used such unpaid positions to substitute for paid workers, without the link to a 'genuine training programme' that offers an exception to minimum wage laws in the United States. But this is just one component of a broader phenomenon of casualization as online platforms provide an important motivation through "socially recognized self-realization." Mark Deuze has noted the trend, internationally, for this increased output to be produced by "a new international division of predominantly flexible, contingent labor" (2007, 238). Similarly Richard Florida (2002, 105) has noted that "today workers carry risk that companies used to absorb".

Commodity audiences generate value in new, more efficient ways in the era of media convergence, as audiences become what Henry Jenkins (2006) terms "prosumers". In response, much media studies scholarship now works to put the productive value of non-professional media labour front and centre in its analysis. As Vicki Mayer puts it, "Collapsing boundaries between producers' identities as workers, the representations they created, and the audiences they served has added significance in the context of the deregulation and liberalization of television markets globally" (2011, 14-15). Despite these 'collapsing boundaries', media workers remain aware of their productive roles as evidenced by ongoing organising and unionisation efforts, which commercially operated online outlets, such as the Huffington Post, have sought to stymie (Nolan 2015).

Faculty, however, have been subject to similar modes of deprofessionalisation as universities have come to rely increasingly on adjunct faculty. In 2014, more than 73 percent of faculty in the US were contingent, an inversion of the situation in the 1960s, when around the same proportion were tenured or tenurable (Ferrara 2015, 110). Irish data paint a similar picture where available, though most universities simply excluded contingent workers from figures provided to a governmentsponsored study, rendering those workers yet more invisible (Cush 2016). Exacerbated by information technology through online teaching and MOOCs, the low pay and low protections that accompany this model mirror those experienced across the creative industries.

And yet, as media studies faculty are increasingly subject to these pressures, they also bear the brunt of expending programmes with fewer resources relative to the rest of the academy. As the Society for Cinema and Media Studies State of the Field 2015 Report noted, "the development and growth of the field...requires an expansion of resources, which, for some units, are quite scarce". Despite "remarkable growth' and increases in course offerings, students, and faculty," many have witnessed the "cannibalizing of students, courses, and resources" from other departments in their institutions (Dove-Viebahn 2015). 
In the context of neoliberalism and austerity, developing a strategy centred around customer demand works to undercut faculty autonomy and benefits. Decision-making gets filtered through a 'rational' budgetary analysis, defensible within increasingly bureaucratic administrative decision-making models, rather than a more holistic pedagogical approach. Even attempts at interdisciplinarity and collaboration in this environment become pretexts for cost-saving and increased productivity among faculty. Seemingly, media studies faculty and students are subject to many of the same institutional pressures, providing fertile ground for new pedagogical approaches. An understanding informed by the political economy of MJCS itself may help develop such an approach.

\section{The Need for Political Economy}

As James Carey, one of the founders of the American cultural studies tradition, argued in his 1978 Presidential Address to AEJMC, "A Plea for the University Tradition", "The principal effect of professionalism is to erode the moral basis of society," begging the question about journalism schools' role within the broader social context. "The modern school of journalism", noted Carey, "begins its teaching from the premises of the profession it serves. I do not mean by this that it simply teaches the current techniques and knowledge of the craft, but that implicitly it transmits the ideology of the profession, often of professionalism in general."

However, the post-professional context brings additional concerns to bear. While Carey (1978) noted professionalism's exclusionary and elitist tendencies, Pilkington (2013) suggests that traditional bulwarks against market forces no longer protect the autonomy and professional standards from capitalism's more debasing dynamics in the media and academic sectors. Arguments that valorise the amateurisation of media production on the grounds of consumer choice (e.g. Jenkins 2006) - or the 'democratisation' of academic knowledge through online platforms - necessarily overlook what is now clear to many faculty and undergraduates alike: neither media nor academic labour offer a likely pathway to secure employment.

Within MJCS programmes, particularly at non-elite academic institutions, we have in many ways moved beyond the cultivation of professionalism and towards as a cultivation of vocationalism. This is not problematic merely in terms of exploitation and inequality. As Carey (1978) warned, anti-professionalism, when taken to an extreme, has the potential to "slip into a vicious anti-intellectualism: an attack on the very idea of competence." As such, narratives that fetishise broad participation may reduce performance of citizenship to a set of consumer choices (Hedges 2011; Keen 2008). At their worst, they may also enable the rise of fascistic populism, as seen through the meme-culture of the alt-right and identitarian movements that strategically promote a politics of irony, nihilism, and depoliticisation (Kumar 2011; Beran 2017).

The need to understand these historical shifts call attention to the demand for a political economic analysis of MJCS. Political economy provides a means by which to read the history of MJCS through a critical attention to the multi-factored way in which institutions and systems of power shape our social lives, by incorporating what Vincent Mosco has identified as the subfield's constitutive attributes: "social change and history, the social totality, moral philosophy, and praxis" (2009, 26). A political economic approach to the history of media studies and its unfolding trajectory can help instructors and students together devise a socially useful critique. The political economy tradition has long provided a mode of analysis to understand the relationships between labour, processes of commodification, and the culture industry. 
As such, we call for a media studies pedagogy that is cognizant of the political economy of media studies itself.

The political economy tradition (PE) has long held a critique of the professionalism within both the media and the academy. Herman and Chomsky's (2002) propaganda model, for example, illuminates the structural and ideological limits of professional journalism for an engaged public. Similarly, McChesney $(2002,78)$ argues that professionalization within the Ivory Tower "encourages depoliticization, while depoliticization makes it far easier to accrue institutional resources". PE's moral institutionalism - its anti-instrumentalism - offers a starting point to move beyond conceiving of education as a commodity which can be exchanged for a wage increase - a view that is yielding diminishing returns anyway. We might understand education in general, and media studies in particular, as part of the larger cultural apparatus central to shaping our democratic potential within a capitalist society. PE allows us to understand how these links between academic and media institutions developed, and how they have historically mutually transformed each other.

Along these lines, McChesney $(2002,83)$ has called for "three-dimensional histories of cultural industries and political fights over their control and development". By shifting attention from the individual consumer to issues such as policy, we also shift from responses grounded in individual agency to those responses which rely on the development of group consciousness, and collaborative interventions. The policy turn, however, has its limits, as suggested by advocates of media justice approaches to activism who emphasise the role of racial and gender hierarchies in rendering policymaking an exclusionary domain (Cyril 2005; Berger 2009; Snorton 2009).

Cultural studies approaches, however, have been adopted within undergraduate curricula largely in the context of developing media literacy skills. But such skills have long been co-opted by the cultural industries. Williams, for example, noted the example of an ad man in the 1940s who credited his introduction to "practical criticism of advertisements" as assisting his later work within industry (2005/1980, 183). Still, Williams and others saw the potential of critical media education as providing a tool for enlightenment and activation of a politically active working class much as Freire (2004/1970) envisaged popular education as prompting conscientization. That is, critical analysis provides a necessary, if not sufficient, condition for political organising. Indeed, Livingstone has argued that the skills-based approach often associated with media literacy, in which evaluation and content creation are seen as part of a suite of competencies that support engagement and learning by the individual, "prioritizes the abilities of the individual over the knowledge arrangements of society" $(2004,10)$. That is, the acquisition of specific skills, absent attention to broader context, is limited in its efficacy.

Attention to structural conditions and policy can foreground collective agency, as opposed to the limited individualised forms of resistance (e.g. Fiske 1987). In a moment where media production is an increasingly universal act - and participation in formal politics is on the decline - we might develop critical pedagogies that privilege collaborative intervention in the media system from the perspective of the point of production rather than consumption. The question becomes: what value do we produce?

Smythe's (1977) formulation - that audiences are not consumers but products, commodified labour power sold by media companies to advertisers - provides an imperfect but useful starting point for considering the institutional relationships between academic programmes, students, and the media industries. Much like audience measurement systems have aimed to derive value, Gill (2014) has noted 
the parallel processes of surveillance and quantification leveraged in management of creative and academic workers. While it has long been the case, it is more apparent than ever that media studies instructors produce our students as an exploitable labour pool for the media industries.

This fact need not be met with cynicism about the democratic potential of media studies. As one of us has argued, "Rather than binding media studies to a rigid structuralism", contemporary scholars use the concept to "illuminate the fluidity of media economies and culture under neoliberalism" (Dolber 2016). In this case, it may help in developing a "politicised language for thinking about the labouring experience of academics and 'creatives"' (Gill 2014, 26). Drawing on British cultural studies' emphasis on working-class agency, while understanding the structural conditions that constrain and undermine professional identity among media and academic workers, we may begin to see that our real power was never derived from our professional codes, but from our productive capacity.

With an understanding of how the academy has become integrated into a broader cultural industry, such a pedagogy can be rooted in a collaborative, collective ethos. Terminologies sometimes differ, but critiques of changes in media industries and the university sector show similar trends, with workplace 'flexibility' playing out through increased freelancing and contract work in media, and adjunctification of academic labour. As precarity within the university expands, MJCS instructors produce graduates as an exploitable labour pool, demonstrating the central role of commodified academic labour in media economics.

As academic workers, as labour, we may begin to challenge the push towards neo-Taylorism without nostalgia for the bygone days of the mid-20th century. This means not simply teaching critical media studies in a way that adds academic credibility to otherwise technical degrees, but working to transform the institutions we inhabit alongside the larger media industry to which our field is intimately linked. The pedagogical goal must not be that students emerge simply with skill sets to be applied in either the low-wage, contingent context many creatives today inhabit, or in the still-important but dwindling number of elite professional settings. Nor should we hold up professional norms developed decades ago, which no longer reflect the values of an actually-existing media system, as a gold standard from which we have fallen and are unlikely to return. Just as some scholars have critiqued Habermas' valorisation of the bourgeois public sphere, on the basis that his presumption that issues of access and inclusion are merely 'empirical' serves to ignore "the conditions of existence of the democratic subject" (Mouffe 2000, 10), so too does a myth of a golden age short-change students whose professional experiences will bear little resemblance to such a state.

Rather, understanding the history of MJCS within the broader context of the political economy of communication may help media scholars prepare students to operate as agentic workers within a largely media(ted) economy. Such an approach may be taken not in a didactic way, but as a point of solidarity where academics acknowledge that their professional lives are being reshaped by the same forces that place their students' futures in jeopardy. In this way, we may foster and support the organising work needed to address the economic and cultural interests of those graduates as they navigate the terrain of capitalist media as part of an active working class. 


\section{References}

Allaway, John. 1967. Thought and Action in Extra-Mural Work in Leicester 1946-1966. University of Leicester Department of Adult Education. Accessed 21 February 2018. http://eric.ed.gov/?id=ED023019

Aronowitz, Stanley. 2000. The Knowledge Factory: Dismantling the Corporate University and Creating True Higher Learning. Boston: Beacon Press.

Bagdikian, Ben. 2000. The New Media Monopoly. New York: Beacon.

Beran, Dale. 2017. 4chan: The Skeleton Key to the Rise of Trump. Medium, February 14. Accessed 21 February 2018. https://medium.com/@DaleBeran/4chan-the-skeleton-keyto-the-rise-of-trump-624e7cb798cb

Berger, Dan. 2009. Defining Democracy: Coalition Politics and the Struggle for Media Reform. International Journal of Communication, 3 (1): 3-22.

Bui, Quoctrung. 2014. What's Your Major? 4 Decades of College Degrees, in One Graph. National Public Radio, May 9. Accessed 21 February 2018. http://www.npr.org/sections/money/2014/05/09/310114739/whats-your-major-fourdecades-of-college-degrees-in-1-graph

Carey, James W. 1978. A Plea for the University Tradition. Journalism Quarterly, 55 (4): 846855.

Cush, Michael. 2016. Report to the Minister for Education and Skills of the Chairperson of the Expert Group on Fixed-Term and Part-time Employment in Lecturing in Third Level Education in Ireland. Accessed 21 February 2018. http://www.education.ie/en/Publications/Education-Reports/Report-to-the-Minister-ofEducation-and-Skills-of-the-Chairperson-of-the-Expert-Group-on-Fixed-Term-and-PartTime-Employment-in-Lecturing-in-Third-Level-Education-in-Ireland.pdf

Cyril, Malkia. 2005. Media and Marginalization. In The Future of Media: Resistance and Reform in the 20th Century, edited by Robert McChesney, Russell Newman and Ben Scott, 97-105. New York: Seven Stories.

Deuze, Mark. 2007. Media Work. Cambridge: Polity Press.

Dolber, Brian. 2016. Blindspots and Blurred Lines: Dallas Smythe, the Audience Commodity, and the Transformation of Labor in the Digital Age. Sociology Compass, 10 (9): 747-755.

Dove-Viebahn, Aviva. 2015. The State of the Field of Film and Media Studies. Report for SCMS. Accessed 21 February 2018.

http://c.ymcdn.com/sites/www.cmstudies.org/resource/resmgr/SCMS StateoftheField2015 .pdf

Eagleton, Terry. 2010. The Death of the University. The Guardian, December 17. Accessed 21 February 2018. https://www.theguardian.com/commentisfree/2010/dec/17/deathuniversities-malaise-tuition-fees

Eurostat. 2016. Information and communication service statistics - NACE Rev. 2. Accessed 21 February 2018. http://ec.europa.eu/eurostat/statisticsexplained/index.php/Information and communication service statistics - NACE Rev. 2

Ferrara, Mark. 2015. Palace of Ashes: China and the Decline of American Higher Education. Baltimore: Johns Hopkins University Press.

Finberg, Howard. 2013. Journalism Schools Need to Adapt of Risk Becoming Irrelevant. Poynter.org, August 9. Accessed 21 February 2018. http://www.poynter.org/2013/scaryfuture-journalism-education/220410/

Fiske, John. 1987. Television Culture. London: Routledge.

Florida, Richard. 2002. The Rise of the Creative Class: And How It's Transforming Work, Leisure, Community and Everyday Life. New York: Basic Books.

Freire, Paulo. 2004/1970. Pedagogy of the Oppressed [Translated by Myra Bergman Ramos; Introduction by Donaldo Macedo]. New York: Continuum.

Gill, Ros. 2014. Academics, Cultural Workers and Critical Labour Studies. Journal of Cultural Economy, 7 (1): 12-30. doi: 10.1080/17530350.2013.861763

Hall, Stuart. 1980. Cultural Studies: Two Paradigms. Media, Culture and Society 2: 57-72. 
Hallin, Dan. 1992. The Passing of the 'High Modernism' of American Journalism. Journal of Communication 42 (3): 14-25. doi:10.1111/j.1460-2466.1992.tb00794.x

Halloran, James. 1999. A Critical, Social Scientific Approach to the Study of Communication Structures and Processes. Jurnal Komunikasi, 15 (1): 1-19.

Halloran, James. 1995. "Some Problems in International Comparative Research." European Journal of Communication 5: 2-3.

Halloran, James. 1978. "Further Development - or Turning the Clock Back?" Journal of Communication 28: 120-132. doi:10.1111/j.1460-2466.1978.tb01607.x

Hedges, Chris. 2011. Death of the Liberal Class. New York: Nation Books.

Herman, Edward and Noam Chomsky. 2002. Manufacturing Consent: The Political Economy of the Mass Media. New York: Pantheon.

Hesmondhalgh, David. 2002. The Cultural Industries. Thousand Oaks: Sage.

Higgins, Michael D. 2016. Speech at the EUA Annual Conference, April 7. Accessed 21 February 2018. http://www.president.ie/en/media-library/speeches/speech-by-presidentmichael-d-higgins-eua-annual-conference

Jenemann, David. 2007. Adorno in America. Minneapolis: University of Minnesota Press.

Jenkins, Henry. 2006. Convergence Culture: When Old and New Media Collide. New York: NYU Press.

Jowett, Garth, Ian C. Jarvie and Kathryn H. Fuller. 1996. Children and the Movies: Media Influence and the Payne Fund Controversy. New York: Cambridge University Press.

Kahn, Chris. 2015. "What is the ROI of Your College Degree?" Accessed 21 February 2018. http://www.bankrate.com/finance/college-finance/roi-college-degree.aspx

Keen, Andrew. 2008. The Cult of the Amateur: How Blogs, MySpace, YouTube, and the Rest of Today's User-Generated Media Are Destroying Our Economy, Our Culture, and Our Values. New York: Doubleday.

Kuehn, Kathleen and Thomas Corrigan. 2013. Hope Labor: The Role of Employment Prospects in Online Social Production. The Political Economy of Communication 1(1). Accessed 21 February 2018. http://www.polecom.org/index.php/polecom/article/view/9/64

Kumar, Anup. 2011. The Tea Party Movement: The Problem of Populism as a Discursive Political Practice. Javnost-The Public 18 (4), 55-72.

Lee, Richard. 2003. Life and Times of Cultural Studies. Durham: Duke University Press.

Livingstone, Sonia. 2004. Media Literacy and the Challenge of New Information and Communication Technologies. The Communication Review 7, no. 1: 10. doi:10.1080/10714420490280152.

Mattelart, Armand, and Michèle Mattelart. 1998. Theories of Communication, translated by Susan Gruenheck. Thousand Oaks: Sage.

Mayer, Vicki. 2011. Below the Line: Producers and Production Studies in the New Television Economy. Chapel Hill: Duke University Press.

McChesney, Robert. 2004a. Making a Molehill out of a Mountain: The Sad State of Political Economy in U.S. Media Studies. In Toward a Political Economy of Culture: Capitalism and Communication in the Twenty-First Century, edited by Andrew Calabrese and Colin Sparks, 41-64. New York: Rowman and Littlefield.

McChesney, Robert. 2004b. The Problem of the Media: U.S. Communication Politics in the 21st Century. New York: Monthly Review Press.

McChesney, Robert. 2002. Whatever Happened to Cultural Studies? In American Cultural Studies, edited by Catherine A. Warren, 76-92. Urbana: University of Illinois Press.

McChesney, Robert. 1992. Off-Limits: An Inquiry into the Lack of Debate Over the Ownership, Structure, and Control of Mass Media in U.S. Political Life. Communication 13: 1-19.

Miller, Toby. 2014. Blow Up the Humanities. Philadelphia: Temple University Press.

Mosco, Vincent. 2009. The Political Economy of Communication [Second edition]. Thousand Oaks: Sage. 
Mouffe, Chantal. 2000. Deliberative Democracy or Agonistic Pluralism. Ed. Institute for Advanced Studies, Vienna. Political Science Series 72. Accessed 21 February 2018. https://www.ihs.ac.at/publications/pol/pw 72.pdf

Nerone, John. 2015. The Media and Public Life: A History. Malden: Polity Press.

Nerone, John, ed. 1995. Last Rights: Revisiting Four Theories of the Press. Urbana: University of Illinois Press.

Nolan, Hamilton. 2015. Arianna Huffington Goes Conspicuously Silent on the Union Issue. On Gawker.com. Accessed 21 February 2018. http://gawker.com/arianna-huffington-goesconspicuously-silent-on-the-uni-1748345970

O'Connor, Alan. 1989. Raymond Williams: Writing, Culture, Politics. Oxford: Basil Blackwell Ltd.

Pew Research Center. 2017. Sharp Partisan Divisions in Views of National Institutions. Accessed at 21 February 2018. http://assets.pewresearch.org/wpcontent/uploads/sites/5/2017/07/11101505/07-10-17-Institutions-release.pdf

Pilkington, Lionel. 2013. 'Crisis? What Crisis?': The Humanities and Neoliberalism in Ireland. The Irish Review 46: 35-40.

Perlin, Ross. 2013. Black Swan Event: The Beginning of the End of Unpaid Internships. Time, June 13. Accessed at 21 February 2018. http://business.time.com/2013/06/13/black-swan-event-the-beginning-of-the-end-ofunpaid-internships/

Pickard, Victor. 2014. America's Battle for Media Democracy: The Triumph of Corporate Libertarianism and the Future of Media Reform. New York: Cambridge University Press.

Pooley, Jefferson. 2011. Another Plea for the University Tradition: The Institutional Roots of Intellectual Compromise. International Journal of Communication, 5: 1442-1457.

Reich, Robert. 2014. Why College Is Necessary But Gets You Nowhere. RobertReich.org, November 24. Accessed at 21 February 2018. http://robertreich.org/post/103472733520

Rowland, W. D., and M. Tracey. 1990. Worldwide Challenges to Public Service Broadcasting. Journal of Communication, 40:2 8-27. doi:10.1111/j.14602466.1990.tb02259.x

Schiller, Herbert. 1992. Mass Communications and American Empire. Boulder: Westview.

Schmitt, Jason. 2014. Communication Studies Rise to Relevance. The Huffington Post, October 22. Accessed at 21 February 2018. http://www.huffingtonpost.com/iasonschmitt/communication-studies-ris b 6025038.html

Shepherd, Jessica. 2012. Number of Universities Offering Media Studies Degrees 'Tripled in Past 10 Years'. The Guardian, January 26. Accessed 21 February 2018. https://www.theguardian.com/education/2012/jan/26/number-universities-media-studiesup

Simpson, Christopher. 1994. Science of Coercion: Communication Research \& Psychological Warfare, 1945-1960. New York: Oxford University Press.

Smythe, Dallas. 1977. Communications: Blindspots of Western Marxism. Canadian Journal of Communication 1 (3): 1-27.

Snorton, C. Riley. 2009. New Beginnings: Racing Histories, Democracy and Media Reform. International Journal of Communication 3 (1): 23-41.

Stole, Inger. 2005. Advertising on Trial: Consumer Activism and Corporate Public Relations in the 1930s. Urbana: University of Illinois Press.

Thomson, Derek. 2014. Report: Journalists Are Miserable, Liberal, Over-Educated, UnderPaid, Middle-Aged Men Mostly. The Atlantic, May 8. Accessed 21 February 2018. http://www.theatlantic.com/business/archive/2014/05/report-journalists-are-miserableover-educated-under-paid-middle-aged-men-mostly/361891/

United States Bureau of Labor Statistics. 2016. May 2016 National Occupational Employment and Wage Estimates. Accessed at 21 February 2018. https://www.bls.gov/oes/current/oes nat.htm\#27-0000 
Wasko, Janet. 2004. The Political Economy of Communications. In The SAGE Handbook of Media Studies, edited by John D. H. Downing, Denis McQuail, Philip Schlesinger and Ellen Wartella, 309-329. Thousand Oaks: Sage.

Williams, Raymond. 2005/1980. Advertising: The Magic System. In Culture and Materialism: Selected Essays, 170-195. London: Verso.

Williams, Raymond. 1975/1962. Communications. New York: Penguin.

\section{About the Author}

\section{Brian Dolber}

Brian Dolber is Assistant Professor of Communication at California State University, San Marcos, where he teaches courses in media studies. He is the author of Media and Culture in the U.S. Jewish Labor Movement: Sweating for Democracy in the Interwar Era (Palgrave Macmillan 2017). His work has appeared in numerous journals including Communication Theory and Communication, Culture \& Critique.

\section{Andrew O'Baoill}

Andrew O'Baoill is a lecturer in the School of Humanities at the National University of Ireland Galway, where he directs programmes in Journalism. He holds a PhD from the Institute of Communications Research at the University of Illinois. Research focuses include the role of technology and regulation in shaping alternative and community media. 